\title{
A NEW SPRINGSNAIL (HYDROBIIDAE: PYRGULOPSIS) FROM THE LOWER COLORADO RIVER BASIN, NORTHWESTERN ARIZONA
}

\author{
Robert Hershler ${ }^{1}$, Hsiu-Ping Liu ${ }^{2}$, and Lawrence E. Stevens ${ }^{3}$
}

\begin{abstract}
We describe a new springsnail species, Pyrgulopsis hualapaiensis, from the Lower Colorado River basin (northwestern Arizona) that has an ovate- to narrow-conic shell and narrow penis ornamented with a small gland on the distal edge of the lobe. This new species differs from closely similar congeners from the Lower Colorado River basin in several details of female reproductive anatomy and in its mtCOI haplotype (3.0\%-5.0\% mean sequence divergence). Bayesian, maximum parsimony, and distance-based phylogenetic analyses of COI data congruently resolved $P$. hualapaiensis as sister to a divergent lineage of Pyrgulopsis thompsoni in the middle Gila River watershed (southeastern Arizona), although this relationship was not well supported. Pyrgulopsis hualapaiensis is endemic to a spring complex in the Hualapai Indian Reservation that is a culturally sensitive site for the tribe. The small population of these snails appears to be robust despite recent habitat modifications (trenching of outflow and construction of a spring box) and disturbance from road traffic. Future conservation measures could include monitoring of the population and augmentation of the gravel habitat used by these snails.
\end{abstract}

Resumen.-Describimos una nueva especie de caracol de manantial, Pyrgulopsis hualapaiensis, de la cuenca baja del Río Colorado (noroeste de Arizona), que tiene una concha cónica-ovoide estrecha y un pene estrecho ornamentado con una glándula pequeña en el extremo distal del lóbulo. Esta nueva especie es diferente de congéneres similares cercanos de la cuenca baja del Río Colorado en varios detalles de la anatomía reproductiva femenina y en su haplotipo mtCOI (3.0\%-5.0\% secuencia de divergencia media). Un análisis Bayesiano, de parsimonia máxima y análisis basados en distancia filogenética de COI coincidieron en que P. hualapaiensis es hermana de un linaje divergente de Pyrgulopsis thompsoni encontrado en la cuenca media del Río Gila (sureste de Arizona), aunque esta relación no está bien sustentada. Pyrgulopsis hualapaiensis es una especie endémica de una área de manantiales en la reserva india Hualapai, una zona de importancia cultural para la tribu. La población pequeña de estos caracoles parece ser robusta, a pesar de las recientes modificaciones en su hábitat (la excavación de zanjas de salida y la construcción de la estructura que regula y protege el manantial) y la perturbación por el tráfico del camino. Futuras medidas de conservación podrían incluir el monitoreo de la población y el aumento del hábitat de grava utilizado por estos caracoles.

Pyrgulopsis is a large genus (139 species; Hershler et al. 2014b) of hydrobiid gastropods (commonly known as springsnails) that is distributed in springs and other groundwaterdependent habitats in the western United States and northern Mexico. These tiny snails are notable for their typically narrow geographic ranges, often consisting of a single spring or spring complex, which, together with the threats posed by groundwater pumping, diversion of surface flows, and other anthropogenic activities, has made them a current focus of conservation activities throughout the West (Hershler et al. 2014a). The systematics of Pyrgulopsis has been unstable over the past few decades (Hershler and Thompson 1987, Hershler 1994, Thompson and Hershler 2002, Liu and Hershler 2005), and additional changes may be needed as molecular evidence suggests that this morphologically diverse assemblage, which is diagnosed by a combination of several nonunique characters, is not monophyletic (Liu and Hershler 2005). All but 18 of the currently recognized species of Pyrgulopsis were described after 1985 and the delineation of diversity in this genus is still far from complete, as evidenced by a recent series of revisions and descriptions of new congeners (Hershler and Liu 2010, 2012; Hershler et al. 2010, 2013, 2014b).

The Lower Colorado River basin (LCRB) contains 30 Pyrgulopsis species, including 24 endemics, and is one of the 2 principal centers of diversity of the genus (Hershler et al. 2014a). Most of this fauna is concentrated in a few reaches of the upper and middle Gila, Virgin, and White River (Nevada) drainages, while there are comparatively few records

\footnotetext{
${ }^{1}$ Department of Invertebrate Zoology, Smithsonian Institution, Washington, DC 20013-7012. E-mail: hershlerr@si.edu

${ }^{2}$ Department of Biology, Metropolitan State University of Denver, Denver, CO 80217.

${ }^{3}$ Museum of Northern Arizona, Flagstaff, AZ 86001.
} 
from other portions of the approximately 370,000-km² LCRB (Taylor 1987, Hershler and Landye 1988, Hershler 1998, Hershler et al. 2014b). Pyrgulopsis was recently (2008) discovered in a spring just to the south of the Colorado River near the town of Peach Springs (northwestern Arizona), about $95 \mathrm{~km}$ eastnortheast of the most closely proximal previously reported congeneric populations $(P$. conica). Herein we describe this snail as a new, locally endemic species based on morphological and genetic evidence, and assess its phylogenetic relationships.

\section{METHODS}

Specimens of the new species were collected by hand and with a small sieve. A portion of the material was relaxed with menthol crystals and fixed in dilute formalin for anatomical study, while the remaining specimens were directly preserved in $90 \%$ ethanol for mtDNA sequencing. Types and other voucher material for the new species were deposited in the Smithsonian Institution's National $\mathrm{Mu}-$ seum of Natural History (USNM) collection.

Five females and 5 males (all adults) from the single locality of the new species were dissected; a larger series of adult males was examined to assess variation in penial morphology. Variation in the number of cusps on the radular teeth was assessed using the method of Hershler et al. (2007). Other methods of morphological study and descriptive terminology are those used in recent taxonomic investigations of Pyrgulopsis (Hershler 1998, Hershler et al. 2003a). Shell parameters were compiled and analyzed using Systat for Windows 11.00.0 (SSI 2004).

Genomic DNA was extracted from entire snails using a CTAB protocol (Bucklin 1992). Specimens were analyzed for mtDNA individually. A 658-bp segment of cytochrome $c$ oxidase subunit I (COI) corresponding to "Folmer's fragment" (Folmer et al. 1994) was amplified and sequenced with primers LCO1490 and HCOI2198 following the protocols of Liu et al. (2003). Sequences were determined for both strands and then edited and aligned using Sequencher ${ }^{\circledR}$ version 5.01. Five specimens of the new species were sequenced to assess variation; the new sequence reported herein was deposited in GenBank under accession number KU720383.
A BLAST analysis (http://nlast.ncbi.nlm.nih .gov/Blast.cgi) confirmed the genetic distinctiveness of the novelty described herein. In order to generate easily readable trees, our final phylogenetic analyses were based on a small data set containing the COI haplotype detected in the new species and previously published sequences of LCRB congenersP. conica Hershler, 1988; P. montana Hershler 1998; P. morrisoni Hershler 1988; P. simplex Hershler, 1988; and P. thompsoni Hershler, 1988-that closely resemble this novelty in shell shape and penial morphology. Additional analyses of several large COI data sets (not presented herein) confirmed that the closest relatives of the new species were among this group of congeners. The type species of the closely related eastern North American genus Marstonia (M. lustrica) was used to root the trees (per Hershler et al. 2003b). The COI sequences for all but the new species were obtained from GenBank. The collection localities for the genetic samples of the new species and other congeners that were included in the analyses are shown in Fig. 1.

MrModeltest 2.3 (Nylander 2004) was used to obtain an appropriate substitution model (using the Akaike information criterion) and parameter values for the phylogenetic analyses. This program selected HKY + I + G model parameters as the best-fit model for the COI data set. Phylogenetic analyses were performed using 4 different methodologies: distance, maximum parsimony (MP), maximum likelihood (ML), and Bayesian inference. The distance, MP, and ML analyses were performed using PAUP*4.0b10 (Swofford 2002), and the Bayesian analysis was conducted using MrBayes 3.2.5 (Ronquist and Huelsenbeck 2003). For the distance analysis, HKY distance was used to generate a neighbor-joining (NJ) tree (Saitou and Nei 1987). The MP analysis was conducted with equal weighting, using the heuristic search option with tree bisection reconnection branch-swapping and 100 random additions. The ML analysis was performed using the HKY + I + G model; a HKY distance-based NJ tree was used as the initial topology for branch-swapping. Node support was evaluated by 10,000 bootstrap pseudoreplicates except for the ML analysis, for which support values were based on 1000 replications. For the Bayesian analysis, Metropolis-coupled Markov chain Monte Carlo 


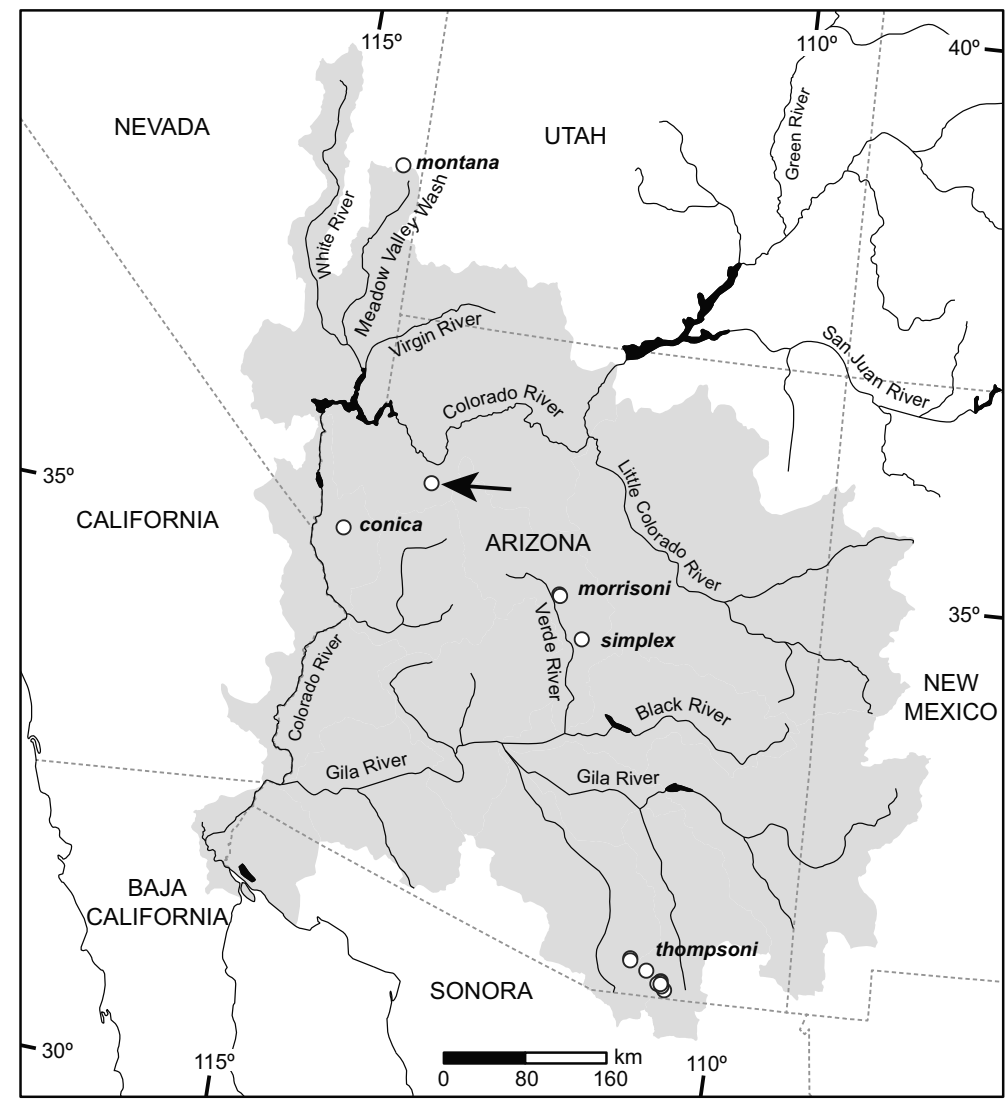

Fig. 1. Map of the lower Colorado River basin (shaded gray) showing the collection localities for the Pyrgulopsis species used in the molecular phylogenetic analyses. The arrow points to the area inhabited by the new species (upper Peach Springs).

simulations were run with 4 chains (using the model selected through MrModeltest) for 2,000,000 generations. Markov chains were sampled at intervals of 10 and 1000 generations to assess the possible autocorrelation issue. We used the default settings for the priors on topologies and the HKY $+\mathrm{I}+\mathrm{G}$ model parameters selected by MRMODELTEST as the best-fit model for this analysis. At the end of the analysis, the average standard deviation of split frequencies was 0.0028 and the Potential Scale Reduction Factor (PSRF) was 1 , indicating that the runs had reached convergence. The sampled trees with branch lengths were used to generate a 50\% majorityrule consensus tree, with the first $25 \%$ of the samples removed to ensure that the chain sampled a stationary portion.

Genetic distances within and between samples were calculated using MEGA6 (Tamura et al. 2013), with standard errors estimated by 1000 bootstrap replications with pairwise deletion of missing data. Since MEGA does not contain the HKY model that was selected by MrModeltest, we used the Tajima-Nei distance, which is the nearest model.

\section{SySTEMATICS}

Family Hydrobiidae Troschel, 1857

Subfamily Nymphophilinae Taylor, 1966

Genus Pyrgulopsis Call and Pilsbry, 1886

Type species: Pyrgula nevadensis Stearns, 1883, by original designation.

Diagnosis: Liu and Hershler (2005:296).

\section{Pyrgulopsis hualapaiensis, new species}

TyPeS.-Holotype, USNM 1248611 (a dry shell), Upper Peach Springs, outflow just below concrete weir, Hualapai Indian Reservation, Mohave County, Arizona, $35.5786^{\circ} \mathrm{N}$, 


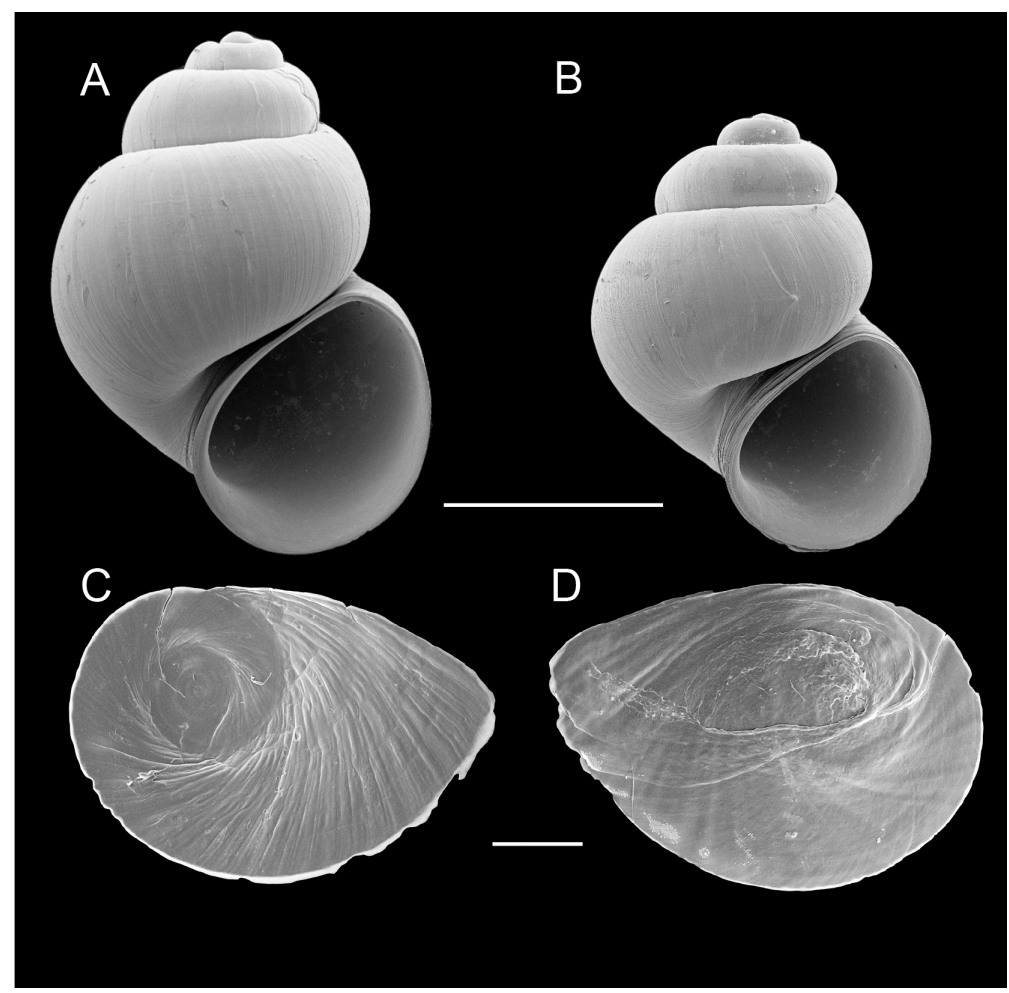

Fig. 2. Scanning electron micrographs of shells and opercula of Pyrgulopsis hualapaiensis: A, holotype, USNM 1248611; B, paratype, USNM 1266144; C, operculum, outer side, USNM 1266144; D, operculum, inner side, USNM 1266144. Scale bars: A, B $=1.0 \mathrm{~mm}$;, $\mathrm{D}=200 \mu \mathrm{m}$.

$113.4314^{\circ} \mathrm{W}, 1280 \mathrm{~m}$ elevation, coll. $\mathrm{RH}$ and LS, 16 May 2014. Paratypes (from same lot), USNM 1266144 (approximately 250 dry shells and alcohol-preserved specimens).

Eтymology.-The species name is an adjective referring to the Hualapai Indian Reservation.

REFERred Material.-ARIZONA. Mohave County: topotypes, USNM 1247929 (dry shells), coll. LS, 28 May 2010; USNM 1248612 (dry shells and alcohol-preserved specimens), coll. LS, 9 January 2014; USNM 1259458 (dry shells and alcohol-preserved specimens), coll. LS, 24 July 2014.

Diagnosis.-A small species of Pyrgulopsis having a narrowly umbilicate, ovate- to narrowconic shell with rounded whorls. Penis having a small lobe and long filament; ornament consisting of a small (terminal) gland on the distal edge of the lobe. Differs from closely similar LCRB congeners in having a vertically oriented coiled oviduct, smaller bursa copulatrix, larger pallial section of the albumen gland, subterminal opening of the capsule gland; and in its mtCOI haplotype (see "Molecular Analysis" section). Pyrgulopsis hualapaiensis is further differentiated from closely related (see "Molecular Analysis" section) P. conica and P. thompsoni in having a shorter penial lobe, longer penial filament, and smaller terminal gland; and a more anteriorly positioned seminal receptacle, respectively. Morphologically similar LCRB congeners are illustrated in Hershler and Landye (1988) and Hershler (1998).

DESCRIPTION.-Shell ovate- to narrow-conic (Fig. 2A-B); height ranging from 2.2 to 2.8 $\mathrm{mm}$; whorls $4.00-4.25 \mathrm{~mm}$. Periostracum tan. Teleoconch whorls medium convex, frequently shouldered, sutures impressed, last whorl sometimes very slightly loosened behind aperture; smooth apart from collabral growth lines. Aperture medium sized, ovate, angled above. Inner lip complete, narrowly adnate or slightly disjunct, slightly thickened internally; columellar shelf usually absent, very narrow when present; outer lip thin, orthocline. Umbilicus 


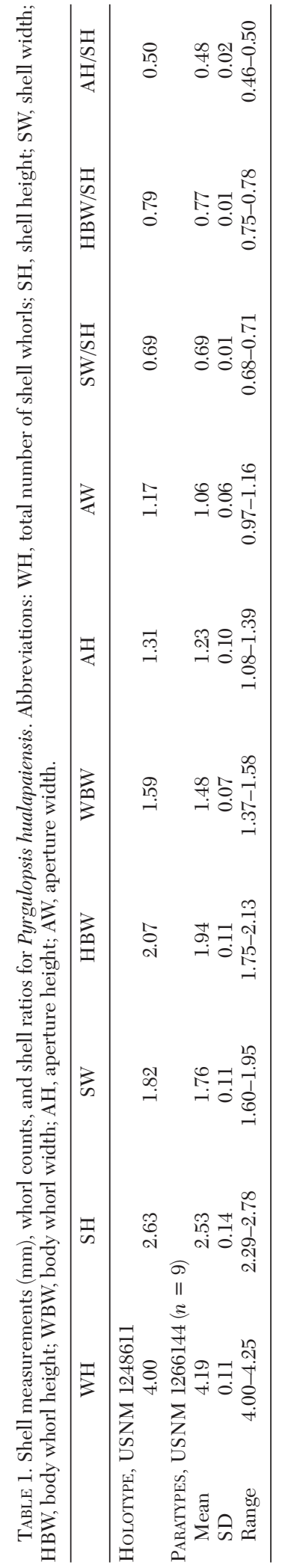

narrow. Shell measurements and whorl counts for the holotype and paratypes are given in Table 1.

Operculum thin, amber, nuclear region somewhat darker, multispiral with eccentric nucleus; outer side smooth (Fig 2C); attachment scar border slightly thickened (Fig. 2D). Radula (Fig. 3A) with about 50 well-formed rows of teeth. Central teeth about $25 \mu \mathrm{m}$ wide, cutting edge concave (Fig. 3B); lateral cusps 4-6; central cusp pointed, parallel-sided proximally; basal cusp 1, small; basal tongue V-shaped, about as long as lateral margins. Lateral tooth face nearly square or rectangular, central cusp pointed (Fig. 3C); lateral cusps 2-3 (inner), 3-4 (outer); outer wing about $180 \%$ length of cutting edge; basal tongue weakly developed. Inner marginal teeth having 20-24 cusps (Fig. 3D). Outer marginal teeth having 23-29 cusps; inner edge with rectangular wing (Fig. 3E). Radula data were from USNM 1266144.

Animal rather lightly pigmented. Cephalic tentacles pale or having a small patch of grey-black pigmented proximally, snout and sole grey-black. Pallial roof and gonads having diffuse black pigment. Ctenidial filaments 17-20 $(n=5)$. Prostate gland small, peashaped. Anterior vas deferens having pronounced bend on columellar muscle. Penis medium sized, rectangular, with a few folds along inner edge; filament long, narrow, tapering, horizontal; lobe small, nearly square, horizontal (Fig. 4A). Penis having a small terminal gland on distal edge of lobe (Fig. 4B), usually on ventral surface $(n=9)$. Penial duct nearly straight, very narrow, near outer edge. Filament and distal portion of penis darkly pigmented with black granules. Female glandular oviduct and associated structures shown in Fig. 4C. Coiled oviduct vertical, proximal arm strongly kinked. Bursa copulatrix very small, ovate, slightly oblique, partly overlapped by albumen gland. Bursal duct long, narrow, opening from distal edge, sometimes partly embedded in albumen gland, junction with common duct a little in front of posterior wall of pallial cavity. Seminal receptacle small, sac-like, folded, overlapping proximal portion of bursal duct. Albumen gland with rather large pallial section. Capsule gland slightly shorter than albumen gland. Genital aperture slit-like, opening well proximal to the anterior edge of the gland. 


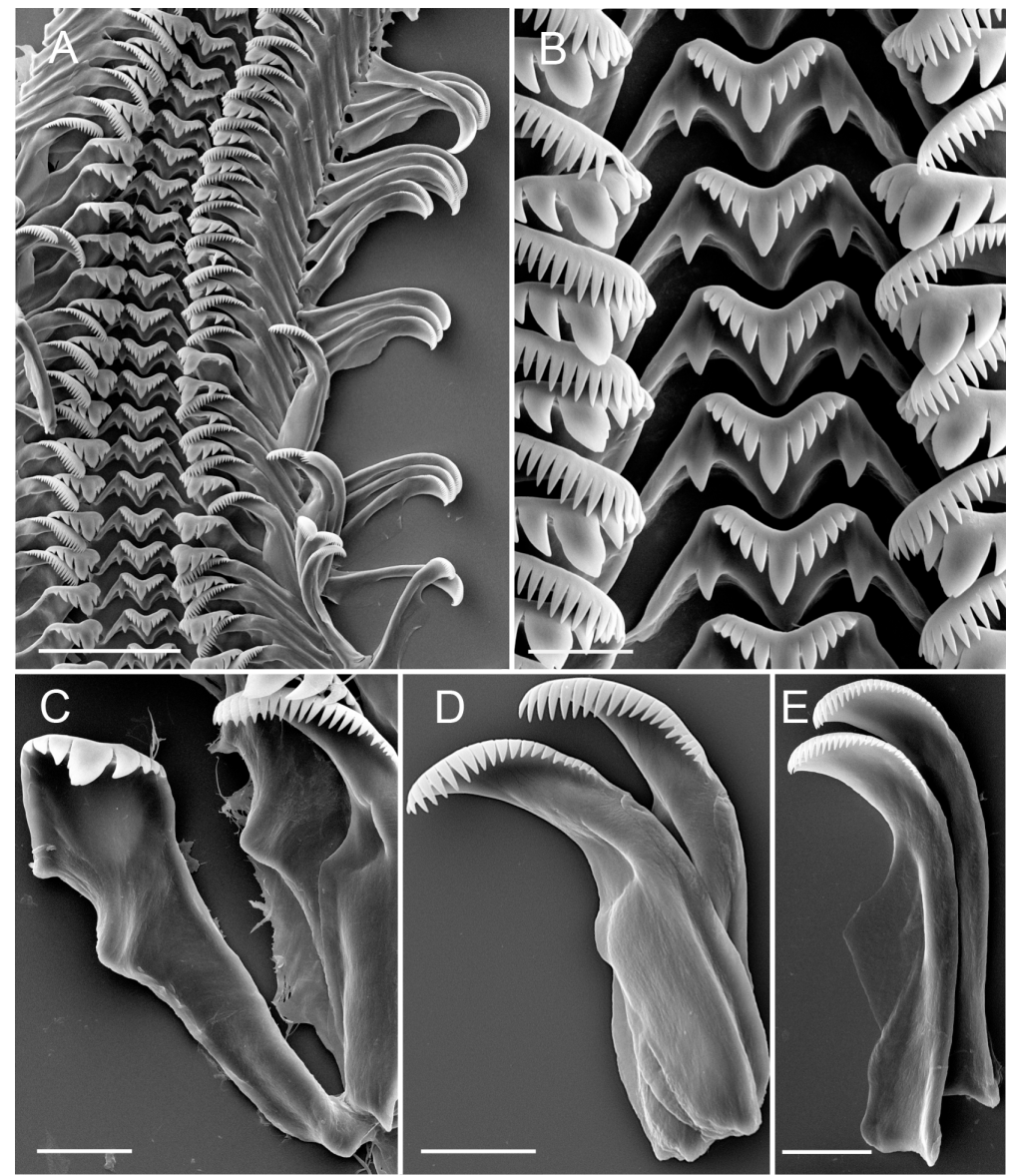

Fig. 3. Scanning electron micrographs of radula of Pyrgulopsis hualapaiensis, USNM 1266144: A, portion of radula ribbon; B, central teeth; $\mathbf{C}$, lateral and inner marginal teeth; $\mathbf{D}$, inner marginal tooth; $\mathbf{E}$, outer marginal tooth. Scale bars: $\mathrm{A}=50 \mu \mathrm{m}, \mathrm{B}-\mathrm{E}=10 \mu \mathrm{m}$.

DisTRIBUTION AND HABITAT.-Pyrgulopsis hualapaiensis is endemic to upper Peach Springs, a small, shallow-gradient, east-facing hillslope spring complex that emerges on the upper terraces of Peach Springs Wash, approximately $6.5 \mathrm{~km}$ north of the town of Peach Springs, and $30 \mathrm{~m}$ west of the much larger rheocrene complex known as Peach Springs. (The 2 spring complexes are collectively named "Peach Springs" on recent USGS topographic maps.) The vegetation of the surrounding landscape is dominated by Prosopis, Acacia, Juniperus and other desert shrubs and grasses; the spring complex is not much shaded by surrounding slopes. Upper Peach Springs was a hillslope springs ecosystem (sensu Springer and Stevens 2009) originally, but was excavated into a 25-m-long trench more than 40 years ago, apparently to focus flow. The spring now flows approximately $20 \mathrm{~m}$ from the source area through a dense stand of Typha domingensis with overstory Populus fremontii. The trench channel is almost entirely floored with $>0.5$-m-deep mud which does not appear to be suitable habitat for $P$. hualapaiensis. Near the pour-out, the outflow stream shallows to $10-20 \mathrm{~cm}$ and passes across about $1 \mathrm{~m}$ of pea gravels, finally discharging over a concrete spring box into a road ditch (Fig. 5). Pyrgulopsis hualapaiensis has been found in the gravel-floored portion of the channel, on the face of the spring box, and among the Nasturtium officinale growth on those surfaces and in the uppermost $3 \mathrm{~m}$ of the roadside ditch. Densities up to 2765 snails $\cdot \mathrm{m}^{-2}$ were measured on artificial sampling plates 

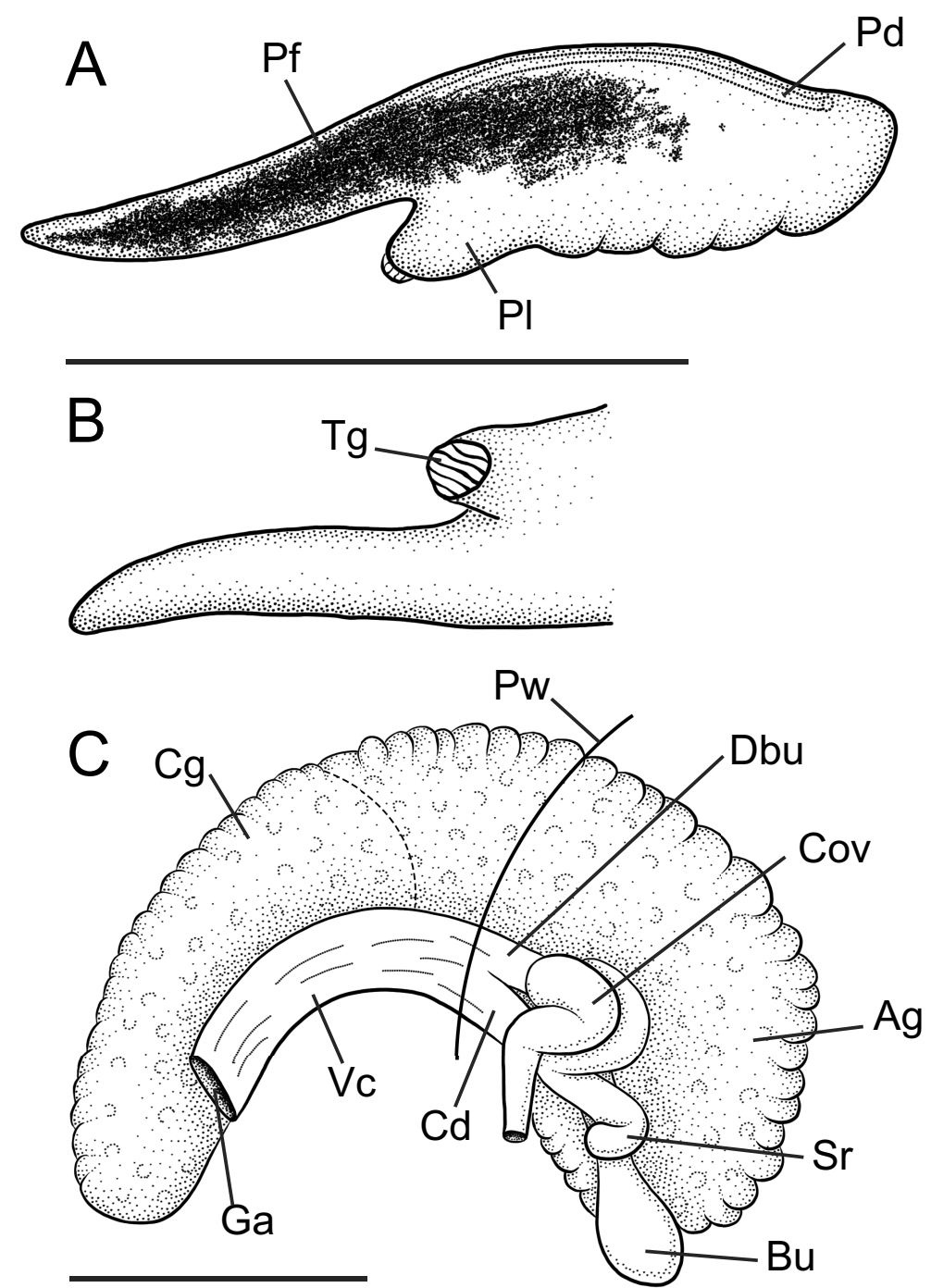

Fig. 4. Reproductive anatomy of Pyrgulopsis hualapaiensis, USNM 1266144: A, penis, dorsal surface; B, penis, ventral surface; C, female glandular oviduct and associated structures (viewed from left side). Abbreviations: Ag, albumen gland; $\mathrm{Bu}$, bursa copulatrix; $\mathrm{Cd}$, common duct of seminal receptacle and coiled oviduct; Cg, capsule gland; Cov, coiled oviduct; Dbu, bursal duct; Ga, female genital aperture; Pd, penial duct; Pf, penial filament; Pl, penial lobe; $\mathrm{Pw}$, posterior wall of pallial cavity; Sr, seminal receptacle; Tg, terminal gland; Vc, ventral channel of capsule gland. Scale bars: $500 \mu \mathrm{m}$.

several months after they were installed on 16 May 2014. The following data were collected during 3 visits to the spring in 2014: water temperature, $18.5-20.2{ }^{\circ} \mathrm{C}$; specific conductance, $658-822 \mu \mathrm{S} \cdot \mathrm{cm}^{-1}$; $\mathrm{pH}, 6.95-7.43$; salinity, 290-360 ppm.

RemarKs.-Hualapai Tribal staff found a single empty Pyrgulopsis shell on 13 May 2008 during routine benthic monitoring in the outflow channel downstream from Peach Springs, across the road from Upper Peach Springs. Sub- sequent failure to find specimens in that spring complex led LS to search nearby Upper Peach Springs where the extant population of P. hualapaiensis was discovered.

This new species is assigned to Pyrgulopsis based on the superficial position of the bursa copulatrix and bursal duct on the albumen gland, presence of a single seminal receptacle, and diffuse pattern of mantle pigmentation (per Liu and Hershler 2005:296). The penial morphology of $P$. hulapaiensis conforms to that 


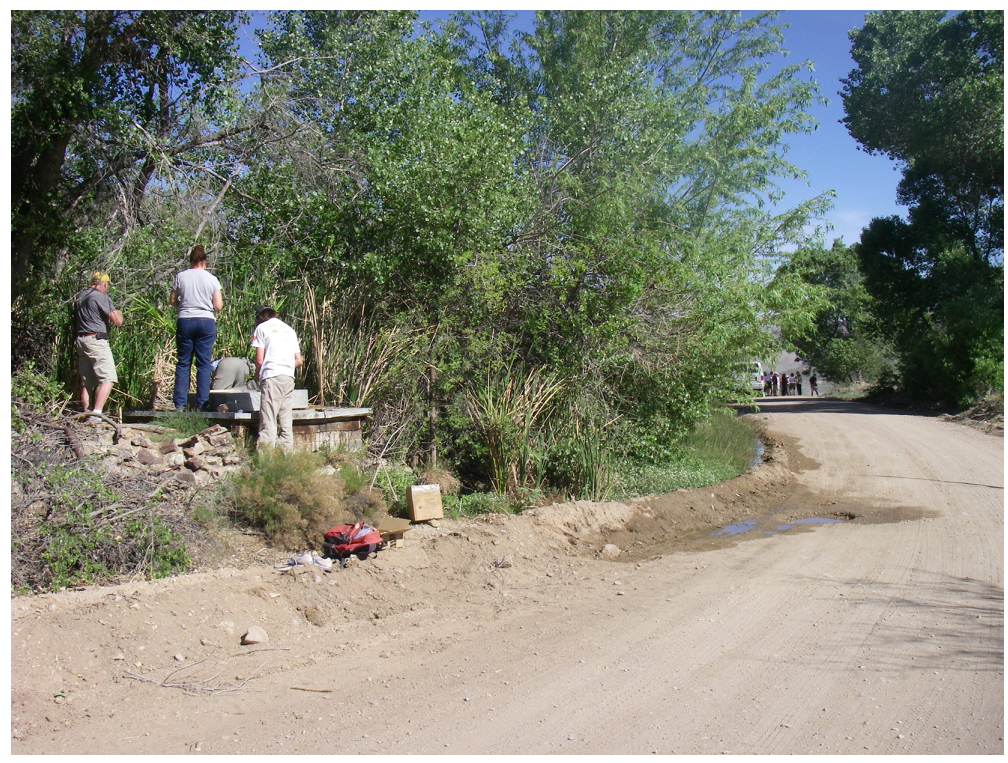

Fig. 5. Photograph of upper Peach Springs (taken on 16 May 2014), the type locality of Pyrgulopsis hualapaiensis. The outflow discharges across the concrete spring box before entering the ditch along the edge of the road.

TABLe 2. Percent COI sequence divergence (mean with standard deviation in parentheses) among Pyrgulopsis hualapaiensis and morphologically similar species in the lower Colorado River basin.

\begin{tabular}{|c|c|c|c|c|c|c|}
\hline & P. hualapaiensis & P. conica & P. montana & P. morrisoni & P. simplex & P. thompsoni \\
\hline P. hualapaiensis & - & & & & & \\
\hline P. conica & $3.0(0.7)$ & - & & & & \\
\hline P. montana & $3.5(0.8)$ & $3.0(0.7)$ & - & & & \\
\hline P. morrisoni & $5.0(0.9)$ & $4.4(0.8)$ & $4.4(0.8)$ & $0.7(0.2)$ & & \\
\hline P. simplex & $4.3(0.8)$ & $3.8(0.8)$ & $3.8(0.7)$ & $3.8(0.7)$ & - & \\
\hline P. thompsoni & $3.3(0.6)$ & $3.3(0.6)$ & $3.5(0.7)$ & $4.4(0.8)$ & $3.8(0.7)$ & $1.8(0.3)$ \\
\hline
\end{tabular}

of a large, informally recognized species group that is widely distributed in the West ("species group 3,” Hershler and Sada 2002). Molecular evidence suggests that this assemblage is not monophyletic (Liu and Hershler 2005).

\section{Molecular Analysis}

A single COI haplotype was detected in P. hualapaiensis which differs from the sequences of morphologically similar LCRB congeners by $3.0 \%-5.0 \%$ (Table 2). The Bayesian, $\mathrm{MP}$, and NJ analyses congruently depicted $P$. hualapaiensis as most closely related to a divergent lineage of $P$. thompsoni (haplotype Ptho5; Hurt 2004) with this clade in turn sister to $P$. conica; however, these relationships were not well supported in any of the trees. The Bayesian topology is shown in Fig. 6. The relationships of $P$. hualapaiensis were not resolved in the ML tree in which all terminals had very short branch lengths.

\section{Discussion}

Our finding that P. hualapaiensis may be most closely related to snails (currently assigned to $P$. thompsoni) that are distributed in southeastern Arizona hundreds of kilometers from Peach Springs is somewhat surprising, but nonetheless is consistent with previously published evidence that the molecular phylogenetic relationships within Pyrgulopsis are not tightly linked with geography (Liu and Hershler 2005). Liu and Hershler (2005) attributed this noncongruence of pattern to an early, rapid diversification of the genus that may have been triggered by the complex changes in western topography that occurred during 


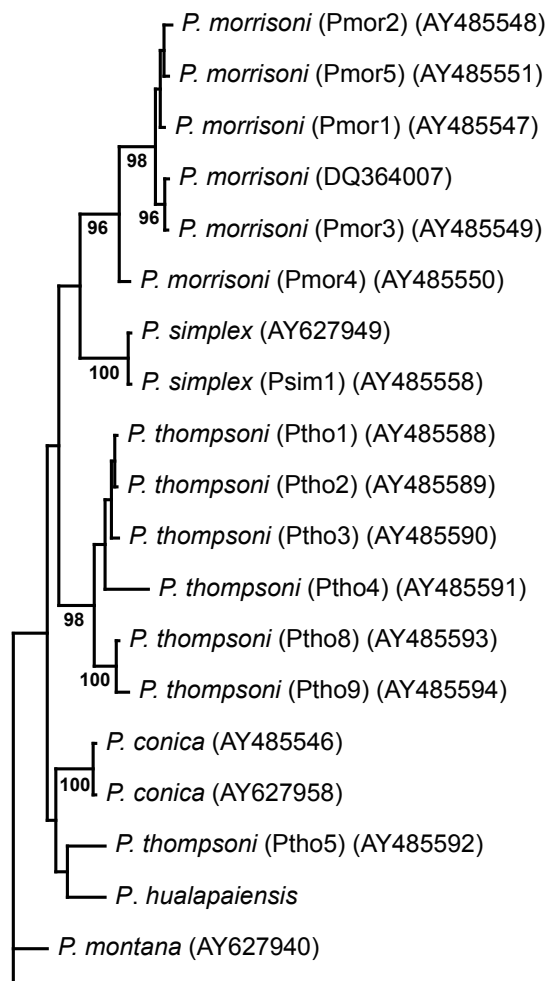

Fig. 6. Bayesian tree based on COI data delineating the phylogenetic relationships of Pyrgulopsis hualapaiensis. Posterior probabilities for nodes are indicated when $>95 \%$. GenBank accession numbers for previously published sequences are given in parentheses.

the late Tertiary. There is also some molecular evidence that the large geographic ranges of several Pyrgulopsis lineages have been shaped, at least in part, by dispersal on waterfowl across topographic barriers (Liu et al. 2003, Liu and Hershler 2007). This interesting subject of Pyrgulopsis biogeography should be revisited after a more robust phylogeny for the genus is available.

The divergent lineage of $P$. thompsoni (Ptho5 haplotype; Hurt 2004) that appears to be sister to $P$. hualapaiensis is probably a distinct species, however the delineation of its taxonomic status is beyond the scope of our paper. Note that this lineage is composed of several recently discovered populations that were assigned to $P$. thompsoni bereft of taxonomic study (Tsai et al. 2007) and was also detected at a low frequency in a sample from the type locality of this species (Peterson Ranch Springs; table 3 in Hurt 2004).
Pyrgulopsis hualapaiensis is endemic to a spring complex that is a culturally sensitive site for the Hualapai Tribe. This aquatic habitat has been altered by trenching to focus flow and construction of a concrete spring box on the side of a heavily used road (BIA 6/Diamond Creek Road). In spite of these modifications, disturbance from road traffic, and the small area occupied by P. hualapaiensis (totaling about $5 \mathrm{~m}^{2}$ ), the population appears to be robust (LS personal observation). The determination of possible conservation activities for this species is under the purview of the Hualapai Tribe but could include seasonal monitoring using artificial substrate samplers and augmentation of habitat within the spring complex by careful, incremental replacement of cattail/ooze habitat with pea gravels. These actions could be conducted initially as an experiment on a small portion of habitat near the spring source and should be carefully 
monitored while respecting the cultural significance of the site.

\section{ACKNOWLEDGMENTS}

We thank the Hualapai Tribe for the assistance and cooperation they provided throughout this study. Yolanda Villacampa measured shells and prepared scanning electron micrographs; Freya Goetz rendered the anatomical drawings and prepared the manuscript figures.

\section{Literature Cited}

BuCKLIN, A. 1992. Use of formalin-preserved samples for molecular analysis. Newsletter of Crustacean Molecular Techniques 2:3.

Folmer, O., M. Black, W. Hoeh, R. Lutz, and R. VriJENHOEK. 1994. DNA primers for amplification of mitochondrial cytochrome $c$ oxidase subunit I from diverse metazoan invertebrates. Molecular Marine Biology and Biotechnology 3:294-299.

Hershler, R. 1994. A review of the North American freshwater snail genus Pyrgulopsis. Smithsonian Contributions to Zoology 554:1-115.

Hershler, R. 1998. A systematic review of the hydrobiid snails (Gastropoda: Rissooidea) of the Great Basin, western United States. Part I. Genus Pyrgulopsis. Veliger 41:1-132.

Hershler, R., T.J. Frest, H.-P. Liu, and E.J. Johannes. 2003a. Rissooidean snails from the Pit River basin, California. Veliger 46:275-304.

Hershler, R., AND J.J. LandYe. 1988. Arizona Hydrobiidae. Smithsonian Contributions to Zoology 459:1-63.

Hershler, R., and H.-P. Liv. 2010. Two new, possibly threatened species of Pyrgulopsis (Gastropoda: Hydrobiidae) from southwestern California. Zootaxa 2343:1-17.

Hershler, R., AND H.-P. LiU. 2012. A new species of springsnail (Pyrgulopsis) from the Owyhee River basin, Nevada. Western North American Naturalist $72: 21-31$.

Hershler, R., H.-P. Liu, and C. Bradford. 2013. Systematics of a widely distributed western North American springsnail, Pyrgulopsis micrococcus (Caenogastropoda, Hydrobiidae), with descriptions of three new congeners. ZooKeys 330:27-52.

Hershler, R., H.-P. Liu, T.J. Frest, and E.J. Johannes. 2007. Extensive diversification of pebblesnails (Lithoglyphidae: Fluminicola) in the upper Sacramento River basin, northwestern United States. Zoological Journal of the Linnean Society 149:371-422.

Hershler, R., H.-P. Liu, and J. Howard. 2014a. Springsnails: a new conservation focus in western North America. BioScience 64:693-700.

Hershler, R., H.-P. LiU, and B.K. Lang. 2010. Transfer of Cochliopa texana to Pyrgulopsis (Hydrobiidae) and description of a third congener from the lower Pecos River basin. Journal of Molluscan Studies 76:245-256.

Hershler, R., H.-P. Liu, and F.G. Thompson. 2003b. Phylogenetic relationships of North American nymphophiline gastropods based on mitochondrial DNA sequences. Zoologica Scripta 32:357-366.
Hershler, R., V. Ratcliffe, H.-P. Liu, B. Lang, and C. HaY. 2014b. Taxonomic revision of the Pyrgulopsis gilae (Caenogastropoda: Hydrobiidae) species complex, with descriptions of two new species from the Gila River basin. ZooKeys 429:69-85.

Hershler, R., AND D. SADA. 2002. Biogeography of Great Basin aquatic snails of the genus Pyrgulopsis. Pages 255-276 in R. Hershler, D.B. Madsen, and D.R. Currey, editors, Great Basin aquatic systems history. Smithsonian Contributions to the Earth Sciences 33.

Hershler, R., and F.G. Thompson. 1987. North American Hydrobiidae (Gastropoda: Rissoacea): redescription and systematic relationships of Tryonia Stimpson, 1865 and Pyrgulopsis Call and Pilsbry, 1886. Nautilus 101:25-32.

HurT, C.R. 2004. Genetic divergence, population structure and historical demography of rare springsnails (Pyrgulopsis) in the lower Colorado River basin. Molecular Ecology 13:1173-1187.

LiU, H.-P., AND R. HERSHLER. 2005. Molecular systematics and radiation of western North American nymphophiline gastropods. Molecular Phylogenetics and Evolution 34:284-298.

Liu, H.-P., AND R. Hershler. 2007. A test of the vicariance hypothesis of western North American freshwater biogeography. Journal of Biogeography 34: 534-548.

Liu, H.-P., R. Hershler, and K. Clift. 2003. Mitochondrial DNA sequences reveal extensive cryptic diversity within a western American springsnail. Molecular Ecology 12:2771-2782.

Nylander, J.A.A. 2004. MrModeltest v2. Program distributed by the author. Evolutionary Biology Centre, Uppsala University, Sweden.

RonQuist, F., AND J.P. Huelsenbeck. 2003. MRBAYES 3: Bayesian phylogenetic inference under mixed models. Bioinformatics 19:1572-1574.

SAITOU, N., AND M. NEI. 1987. The neighbor-joining method: a new method for reconstructing phylogenetic trees. Molecular Biology and Evolution 4:406-425.

Springer, A.E., AND L.E. STEvens. 2009. Spheres of discharge of springs. Hydrogeology Journal 17:83-93.

SWOFFORD, D.L. 2002. PAUP*: phylogenetic analysis using parsimony (and other methods), version 4.08b10. Sinauer Associates, Sunderland, MA.

[SSI] Systat Software, Inc. 2004. Systat ${ }^{\circledR}$ for Windows ${ }^{\circledR}$. Richmond, CA.

Tamura, K., G. Stecher, D. Peterson, A. Filipski, and S. KumAR. 2013. MEGA6: molecular evolutionary genetics analysis version 6.0. Molecular Biology and Evolution 30:2725-2729.

TAYLOR, D.W. 1987. Fresh-water molluscs from New Mexico and vicinity. New Mexico Bureau of Mines and Mineral Resources Bulletin 116:1-50.

Thompson, F.G., And R. Hershler. 2002. Two genera of North American freshwater snails: Marstonia Baker, 1926, resurrected to generic status, and Floridobia, new genus (Prosobranchia: Hydrobiidae: Nymphophilinae). Veliger 45:269-271.

Tsai, J.Y., K. Maloney, and A.E. Arnold. 2007. Biotic and abiotic factors influencing the distribution of the Huachuca springsnail (Pyrgulopsis thompsoni). Journal of Freshwater Ecology 22:213-218.

Received 29 September 2015 Accepted 20 January 2016 